Revista Bioética (c) (i)

Print version ISSN 1983-8042 On-line version ISSN 1983-8034

Rev. Bioét. vol.28 no.1 Brasília Jan./Mar. 2020

Doi: 10.1590/1983-80422020281000

\title{
EDITORIAL
}

\section{Medicine and society}

Tatiana Bragança de Azevedo Della Giustina ${ }^{1}$

1. Segunda Secretária do Conselho Federal de Medicina (CFM), Brasília/DF, Brasil.

Although the first concerns about bioethics took place after the Great Wars, especially after World War II, this field of research only took its current shape in the 1970s. In times of social change, bioethical principlism has a lot to contribute to science and the humanities ${ }^{1}$.

Bioethics arises from the technicalization of medicine, with its scientific advances and the power over life and death, health and disease, quality of life and suffering, in addition to the socio-cultural changes experienced in the 20th century. American researcher Van Rensselaer Potter proposed the creation of some kind of bridge between the area of science and that of the humanities, reflecting, from the perspective of ethics, on human civilization, individual rights and human dignity ${ }^{1,2}$. These circumstances have drastically changed the dynamics of the physician-patient relationship, which is currently based on the principle of the patient's autonomy over their body and therapeutic decisions. From this, self-determination and the importance of the informed consent form are prioritized in medical procedures, both governed by Resolution CNS 466/2012 ${ }^{3}$.

Socially, respect for differences is preached worldwide, especially nondiscrimination and non-stigmatization, in addition to the guarantee of individual rights $^{4}$. In Brazil, these rights are ratified by the 1988 Federal Constitution ${ }^{5}$, especially its Fifth Article. In this regard, the United Nations Educational, Scientific and Cultural Organization ${ }^{6}$ (Unesco) published the Universal Declaration on Bioethics and Human Rights in 2006, whose text was unanimously approved by its 191 member countries on October 19, 2005. In its article 11, the Declaration states that no individual or group should be discriminated against or stigmatized for any reason, which would constitute a violation of human dignity, human rights and fundamental freedoms ${ }^{6}$. This document also included the Universal Declaration on the Human Genome and Human Rights ${ }^{7}$.

In this issue of Revista Bioética, we can observe some reflections on changes in social paradigms over the years to avoid discrimination against specific groups, whether for ethnic, gender-related or religious reasons, as well as political conflicts or those related to sexual orientation. For example, although homosexuality was excluded from the International Classification of Diseases by the World Health Organization ${ }^{8}$ in the mid-1990s, there are still circumstances that require changes in the legal field, with different interpretations from country to country ${ }^{9,10}$.

The difficult role of the physician in communicating bad news to patients in cases of congenital malformations is also addressed in this edition. Part of the difficulty discussed arises, for example, from the need for the physician to manage the ethical and legal implications of the final decision, which is fundamentally a right of the patient.

The concepts of euthanasia, dysthanasia and orthothanasia are also a theme that generates ethical conflicts in the health care area. This is because technology in medicine increasingly allows to artificially extend life; however, it is always questionable whether the disease could have followed its natural outcome. In this context, euthanasia is a way of shortening life, and as such it is not allowed in Brazil - like assisted suicide; in dysthanasia all possible resources are used to

\section{Bioética}

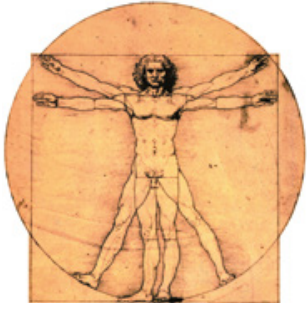


prolong life, even if it brings harm to the patient; and orthothanasia happens when an individual in a state of terminal illness seeks resources to reduce their suffering, avoiding procedures that demean human dignity only to prolong life ${ }^{11}$.

The advance directives of will (DAV - diretivas antecipas de vontade) in Brazil are manifestations of the patient's desire regarding their medical treatment. On August 31, 2012, the Federal Council of Medicine (CFM) published Resolution $1.995 / 2012^{12}$, in which the right of the patient or their legal representative to express their will about medical treatments is recognized ${ }^{13}$. DAV also record the patient's opinion about organ donation - although the actual donation depends on family agreement-, another issue addressed in this edition. In Brazil, this theme is regulated by Law 10.211/2001 ${ }^{14}$, Decree 9.175/2017 ${ }^{15}$ and CFM Resolution 2.173/2017 ${ }^{16}$, which establishes criteria for the diagnosis of brain death.

In times of social networks and intense communication between people, reflections on the perception of medical students about medical confidentiality are crucial and therefore are present in the Medical Student Code of Ethics, published in 2018 by CFM $^{17}$. This issue also presents an analysis of aspects of the judicialization of health in Brazil, especially in the city of Ribeirão Preto, São Paulo, Brazil, based on the right to healthcare, listed in article 196 of the Federal Constitution ${ }^{5}$ as being the duty of the State. Finally, inclusive practices for people with disabilities are analyzed in the syntagmatic structure identity-metamorphosis-emancipation.

Good reading to everyone; certainly, through the addressing of these themes, important insight will be developed in the field of bioethics.

\section{Editor-in-Chief}

\section{References}

1. Pessini L. As origens da bioética: do credo bioético de Potter ao imperativo bioético de Fritz Jahr. Rev. bioét. (Impr.) [Internet]. 2013 [acesso 18 fev 2020];21(1):9-19. DOI: 10.1590/S1983-80422013000100002

2. Beauchamp TL, Childress JF. Principles of biomedical ethics. 7a ed. Nova York: Oxford University Press; 2013.

3. Conselho Nacional de Saúde. Resolução CNS no 466, de 12 de dezembro de 2012. Aprova diretrizes e normas regulamentadoras de pesquisas envolvendo seres humanos. Diário Oficial da União [Internet]. Brasília, no 12, p. 59, 13 jun 2013 [acesso 18 fev 2020]. Seção 1. Disponível: https://bit.ly/37Eo2Ye

4. Godoi AMM, Garrafa V. Leitura bioética do princípio de não discriminação e não estigmatização. Saúde Soc [Internet]. 2014 [acesso 18 fev 2020];23(1):157-66. DOI: 10.1590/S0104-12902014000100012

5. Brasil. Presidência da República. Constituição da República Federativa do Brasil de 1988. Diário Oficial da União [Internet]. Brasília, 5 out 1988 [acesso 18 fev 2020]. Disponível: https://bit.ly/37FWFge

6. Organização das Nações Unidas para a Educação, a Ciência e a Cultura. Declaração universal sobre bioética e direitos humanos [Internet]. Paris: Unesco; 2006 [acesso 18 fev 2020]. Disponível: https://bit.ly/2HznRCP

7. Organização das Nações Unidas para a Educação, a Ciência e a Cultura. Declaração universal sobre o genoma humano e os direitos humanos: da teoria à prática [Internet]. Brasília: Unesco; 2001 [acesso 18 fev 2020]. Disponível: https://bit.ly/39LSy40

8. Organização Mundial da Saúde. Classificação estatística internacional de doenças e problemas relacionados à saúde: décima revisão. São Paulo: Edusp; 1993.

9. Dieter CT. As raízes históricas da homossexualidade, os avanços no campo jurídicos e o prisma constitucional. IBDFAM [Internet]. 2012 [acesso 18 fev 2020]. Disponível: https://bit.ly/2SCW22K

10. Monte NB, Vargas CR, Gutierres Filho PJB, Matos JCM, Silva R, Fernandes JMGA. Ética, estigma e discriminação de grupos vulneráveis no processo educacional. Rev Digital [Internet]. 2009 [acesso 18 fev 2020];14(132):1-12. Disponível: https://bit.ly/2HBK43i

11. Felix ZC, Costa SFG, Alves AMPM, Andrade CG, Duarte MCS, Brito FM. Eutanásia, distanásia e ortotanásia: revisão interativa da literatura. Ciênc Saúde Coletiva [Internet]. 2013 [acesso $18 \mathrm{fev}$ 2020];18(9):2733-46. DOI: 10.1590/S1413-81232013000900029

12. Conselho Federal de Medicina. Resolução CFM no 1.995, de 9 de agosto de 2012. Dispõe sobre as diretivas antecipadas de vontade dos pacientes. Diário Oficial da União [Internet]. Brasília, p. 269-70, 31 ago 2012 [acesso 18 fev 2020]. Seção 1. Disponível: https://bit.ly/38CywZy 
13. Dadalto L, Tupinambás U, Greco DB. Diretivas antecipadas de vontade: um modelo brasileiro. Rev. bioét. (Impr.) [Internet]. 2013 [acesso 18 fev 2020];21(3):463-76. DOI: 10.1590/S1983-80422013000300011

14. Brasil. Presidência da República. Lei no 10.211, de 23 de março de 2001 . Altera dispositivos da Lei no 9.434, de 4 de fevereiro de 1997, que "dispõe sobre a remoção de órgãos, tecidos e partes do corpo humano para fins de transplante e tratamento". Diário Oficial da União [Internet]. Brasília, 24 mar 2001 [acesso 18 fev 2020]. Disponível: https://bit.ly/37JouVj

15. Brasil. Presidência da República. Decreto no 9.175, de 18 de outubro de 2017. Regulamenta a Lei no 9.434, de 4 de fevereiro de 1997, para tratar da disposição de órgãos, tecidos, células e partes do corpo humano para fins de transplante e tratamento. Diário Oficial da União [Internet]. Brasília, 19 out 2017 [acesso 18 fev 2020]. Disponível: https://bit.ly/38F8KUj

16. Conselho Federal de Medicina. Resolução CFM no 2.173, de 23 de novembro de 2017. Define os critérios do diagnóstico de morte encefálica. Diário Oficial da União [Internet]. Brasília, № 240, p. 50-275, 15 dez 2017 [acesso 18 fev 2020]. Seção 1. Disponível: https://bit.ly/2V4kRXk

17. Conselho Federal de Medicina. Código de ética do estudante de medicina [Internet]. Brasília: CFM; 2018 [acesso 18 fev 2020]. Disponível: https://bit.ly/38EBrAF

Tatiana Bragança de Azevedo Della Giustina - PhD - tatiana.giustina@portalmedico.org.br (iD) $0000-0001-5905-4722$ 